Published as: Kate Macdonald, "The Socially Embedded Corporation", The Handbook of Global

Companies, edited by John Mikler, Polity, Cambridge (2013): pp.371-387

\title{
The Socially Embedded Corporation
}

\section{Kate Macdonald}

Bio: Kate Macdonald is a Lecturer at the University of Melbourne, having held previous positions at the London School of Economics and Political Science, the Australian National University, and Oxford University. Her research focuses on the politics of transnational production and business, with a particular focus on social, labour and human rights regulation of global business.

Abstract: This chapter examines the contested social processes through which contemporary global corporations are 'socially embedded': that is, conditioned and constrained by the social relationships in which they participate. The chapter asks how such social embedding occurs, and offers an answer involving a much more overtly politicized account of social embedding than is often presented. Contemporary processes of corporate social embedding are shown to be deeply contested in both normative and sociological terms. Patterns of social embedding that prevail therefore result from the inter-play between a plurality of competing social influences, operating through public and private channels, and at multiple geographical levels. The chapter suggests that analysts of corporate social embedding should therefore focus less on debating supposedly secular societal shifts in expectations of socially responsible corporate conduct, and more on understanding how companies manage the inevitable tensions and trade-offs between competing social demands.

Word count: 8100

Keywords: Social embedding; global corporations; Karl Polanyi; John Ruggie; corporate social responsibility; ethical investment; ethical labelling; corporate accountability campaigns 


\section{The Socially Embedded Corporation}

The contemporary global political economy is cluttered with examples of global companies caught between a multiplicity of competing social expectations and demands. Take, for example, the prominent multinational company Unilever - a company that sells its products across 190 countries, and prides itself on operating as a 'multi-local' multinational company," which is deeply integrated into the social fabric of each country in which it operates. The range of social actors and settings with which the company interacts bring a corresponding diversity of demands for the company to comply with and in some ways actively to support valued social processes and outcomes. For instance, in the UK and the Netherlands, where the company is headquartered, investors expect competitive returns and governments expect compliance with European standards on human rights, transparency, and environmental protection; customers around the world expect high quality and competitively priced goods, adapted for local needs and preferences; governments in countries from which many of the company's agricultural products are sourced expect the company's activities to contribute to processes of growth and development in their countries; and so the list of social demands goes on.

The channels through which these wide ranging social pressures are brought to bear on the company's decision making processes are equally diverse. Such pressures are exerted (among other means) through formal corporate governance arrangements, concerted NGO and network-based campaigns, legal activism, routine forms of government administration and regulation, and broader processes of socialization through which attitudes and behaviours of company management are constituted. How global companies such as Unilever respond to these competing social pressures has significant consequences for the economic and social welfare of individuals and populations coming into contact with the company itself, their products and their suppliers.

Reflecting on examples such as these, it becomes rapidly apparent that the central question confronting those with a theoretical and practical interest in the social and political activities of contemporary corporations is not simply whether they are 'socially embedded' - that is, conditioned and constrained by the social relationships in which they participate. Manifestly they are. That is not to say that corporate activity cannot be 'more' or 'less' socially embedded. Certainly it is possible for companies to be 'less' socially embedded, in the sense that their behaviour is shaped predominantly by fundamental economic drivers underpinned by self-interest and structural forces of supply and demand, or 'more' embedded, whereby such economic drivers are subordinated in significant ways to more contingent social norms and pressures (Polanyi 1944; Block 2003; Gemici 2007). Nevertheless, we can acknowledge such variation of degree, and still accept Karl Polanyi's contention that market activity is "always embedded" in the social in one way or another, however the balance of forces might play out in a particular context (Block 2003).

A more controversial and difficult question - on which this chapter focuses - asks how is global corporate activity socially embedded? This requires us to 'unpack' processes of social embedding in both normative and empirical dimensions, highlighting the contestation that characterises both channels of social influence over companies, and the normative values that sit behind these competing pressures. This exercise not only offers us a more fine-grained empirical picture of how social embedding operates. It also enables a much more overtly political account of social embedding than is commonly presented.

We begin with a conceptual introduction to some of the most influential ways in which the term 'socially embedded' has come to be used in relation to economic activity in general, and global corporate activity in particular. To highlight both the plurality and the deep contestedness of social embedding processes, discussion then breaks down both the multiple normative agendas and then 
the multiple channels of social influence that compete to influence global corporate activity. We then reflect on the context-specific processes through which these influences interact to shape the widely varying activities, roles and responsibilities taken on by contemporary global companies.

\section{What does it mean for companies to be 'socially embedded'?}

\section{The concept}

The term 'embedded' is a highly elastic and arguably overused one. There is reasonably clear agreement on the basic sense in which the term 'socially embedded' is usually applied to companies: that is, it highlights the ways in which companies are conditioned and constrained by the social relationships in which they participate. iii $^{-}$

In one sense the usefulness of the concept of 'embedding' lies precisely in this conceptual breadth, which can accommodate the extremely diverse range of social influences that shape corporate behaviour. These influences come from an array of actors and institutions, including national and regional governments, local and global markets, and more diffuse complexes of territorially grounded social institutions. In order to retain this conceptual breadth, it is useful to deploy the concept of embedding as an expansive umbrella term, which gestures towards a range of social actors and institutions that are external to the organisational container of the company itself, but which contribute in significant ways to shaping corporate behaviour. ${ }^{\text {iv }}$

Nevertheless, if the term embeddedness is used carelessly, its breadth can obscure several important distinctions within both the concept and practice of social embedding. Existing analyses of embedding have dealt with these distinctions in different ways, varying most notably along three dimensions: the level of analysis they focus on (ranging from a broad macro-systemic focus to a narrower focus on actors, institutions and networks); the economic subjects of social embedding they focus on (markets, economic policy regimes or companies); and the way they balance normative versus empirical analysis. We discuss each of these briefly below. Although scholarly literature on the social embeddedness of economic is expansive, the concept is deeply associated in the minds of many with a key set of influential authors. The below discussion focuses on these key thinkers, but also makes reference to the broader traditions in which their writings are located.

\section{Levels of analysis}

One way in which approaches to studying the social embedding of economic activity have varied is the differing levels of analysis through which processes of social embedding have been examined. Although such distinctions are usually blurred and often rather subtle, they can help us understand the varying scope and focus of writings on social embeddedness.

Some of the most influential writings on social embedding come from a prominent collection of economic sociologists and political economists whose analytic lens is fixed at a very broad, macrosociological, and often deeply historicized level. Such theorists have tended to conceptualize social embedding as a pattern of social conditioning of economic activity prevalent during particular phases or forms of capitalism (Polanyi 1944; Jessop 2001). Understood in this way, the concept refers to a 'background' complex of interlocking norms, practices and institutions that exercise a conditioning or regulatory influence over those economic actors that comprise the core subject of investigation.

Foremost in most people's minds among theorists of this bent is Karl Polanyi, whose writings on the social embeddedness of markets have been extremely influential. Although his original focus was on social embedding at the national level, his ideas have enjoyed a revival in recent years, applied in 
adapted ways to a globalizing social and economic environment. Polanyi's (1944) famous account of social embeddedness certainly recognised the importance of transformative social agency, particularly in the form of large-scale social movements demanding that social values be re-asserted against the market, so to speak. Nevertheless, his analytical lens was focused at what we might loosely call a macro-sociological, historical-institutionalist level (Krippner and Alvarez 2007).

This approach can be contrasted to that of (Granovetter 1985), another influential economic sociologist writing on this subject, who has characterised embeddedness in network terms, focusing on how economic actors orient themselves to one another in the market. Many have suggested that the latter conception is too narrow, losing sight of the macro-institutional picture that Polanyi accentuated (Krippner and Alvarez 2007; Beckert 2009). Nevertheless, both institution- and network-based conceptualizations can be useful in complementary ways, highlighting, on the one hand, the rule/norm/script-governed nature of market activity, and on the other, its socialinteractive character.

\section{Economic subjects of embedding}

Accounts of social embedding have also varied in notable ways with regard to the kinds of economic actors and processes whose 'social embedding' is being theorized: the economic subjects of social embedding, in other words. In concrete terms, that is to say that some approaches have focused on the embedding of markets, others have focused on the embedding of economic policy regimes, and only a sub-set of these have explicitly focused on the embedding of (global) companies. Although this distinction is not always explicitly highlighted, the material channels of social embedding, as well as the normative principles with respect to which embedding occurs, usually differ importantly across different economic subjects. Because we are particularly interested in applying and adapting analyses of social embedding to global companies, this is an especially important distinction to tease apart in this chapter.

Polanyi's influential analysis was cast in terms of socially embedded 'markets', and this is perhaps still the most common way in which the notion of socially embedded economies is conceptualised. Although all economic and social activity can be described as "embedded", the focus of Polanyi's analysis is specifically on market activity-that is, activity related to the exchange of commodities through a price-driven coordination mechanism. In this context, embeddedness has to do essentially with the constitutive institutions and networks of interaction that shape market activity. Many of the analytical tools developed to analyse socially embedded markets certainly translate to the analysis of socially embedded corporate activity, though the translation is imperfect. In particular, as we will see, Polanyi's macro-historical analysis of societal shifts first towards a 'market society', and then back towards strengthened patterns of social embedding, require some adaption before they can be applied to a fine-grained analysis of how processes of social embedding vary in relation to different kinds of companies, in distinct social contexts.

Economic policy regimes comprise another kind of economic institution whose social embedding has been widely analysed. John Ruggie's influential writings on what he called 'embedded liberalism' reflected a way of thinking about a political regime of social embeddedness (Ruggie 1982). Ruggie used this term to capture an interpretation of the national and international economic policy institutions established under the post-WWII 'Bretton Woods' regime. He characterised these as a kind of grand 'social bargain' through which liberal markets could be contained, socially legitimized and in turn rendered politically sustainable after a period of tumultuous change and conflict in the global order (Ruggie 1982; Ruggie 2008; Abdelal and Ruggie 2009). This approach offers a useful example of how the concept of embedding can be applied with a narrower institutional focus than Polanyi's more epochal, society-wide view. Nevertheless, Ruggie's early focus on the design of (mainly) trade and macroeconomic policy institutions clearly concentrated on distinct normative and 
institutional agendas to those most relevant to the social embedding of global companies, on which we focus here.

More recently, Ruggie himself, together with a range of others, have worked to adapt earlier writings on social embedding to analysis of global companies, and the changing social expectations placed on them against a backdrop of social and economic globalization (Ruggie 2003; Utting 2005). Ruggie's early work on this theme focused on voluntary 'global governance' initiatives such as the UN's Global Compact, assessing their contribution to embedding corporate activity in social norms. More recently Ruggie's work in his capacity as Special Representative to the United Nations on Business and Human Rights has expanded this focus to encompass a broader range of legal and quasi-judicial instruments, alongside voluntary mechanisms of social embedding (Ruggie 2008). Much of this work has however been positioned primarily within a human rights law framework, and has tended not to be articulated within the more sociological language of 'embedding'.

\section{Normative versus empirical focus}

To adapt broader traditions of social embedding to a more focused analysis of global companies, we require analytical tools of two kinds. First, we must analyse the distinctive normative demands that have been invoked by those making social claims on global companies. Second, we need a means of analysing the distinct sociological channels through which global companies are socially embedded. Typically, analyses of embedding encompass both normative and empirical dimensions, though they tend to be mixed in together in rather ambiguous ways. Polanyi for example was making an empirical claim when he suggested that a more embedded market was one subjected to greater discipline by social institutions. But he was also making a moral claim about what he saw as an urgent need to impose this control, lest the free market ravage the society that gave birth to it.

Certainly, some writers on social embedding largely sidestep normative questions, focusing instead on detailed empirical analysis of the features and dynamics of contrasting political and economic institutions in which corporate behaviour is constituted and constrained. The 'varieties of capitalism' tradition of comparative political economy exemplifies this approach (Hall and Soskice 2001; Marshall, Mitchell et al. 2008; Mikler 2009), as do many studies of comparative corporate governance(Jacoby 2004). Nevertheless, much writing on social embedding is very explicit in viewing 'social' interests or values as standing apart from, and often in some kind of normative tension with, economic and financial interests of a narrower kind. Those who use the language of social embedding therefore usually intend this to signal a normative commitment to the goal of disciplining the free market in the interests of wider public interests (Jessop 2001). As Sen puts it, the notion of social embedding is in this way fundamentally about how private relations of power operating through markets can be subordinated to "social values that we can defend ethically" (Sen 2009).

What such overtly normative conceptions of social embedding often downplay, however, is the diversity of social norms that are usually at work, competing for influence over corporate decisions in any given context. The social norms that drive the embedding of corporate behaviour can be 'social' - in the sense of conditioning and constraining more narrowly construed economic goalswithout conforming to a distinctively 'progressive' (leftist liberal) normative position of the kind often assumed. We can therefore deploy the concept of social embeddedness to explain deviations from 'progressive' labour and social practices just as usefully we can apply it to explain progressive patterns of corporate behavioural change. Indeed, as we see below, processes of social embedding are almost always characterised by overt contestation surrounding the substance of the social norms in which corporate behaviour is anchored.

To explore these contested dynamics of social embedding in greater depth, it is therefore useful to disentangle and examine in turn: first, the some of the competing social norms through which the 
embedding of global corporate activity occurs; and second, some of the multiple institutional channels through which competing social pressures on corporate behaviour play out.

\section{Competing normative demands on global companies}

Typically, there is contestation concerning both the basic purposes and values that social institutions (in general) are expected to promote, and the appropriate roles and responsibilities of corporations (in particular) in advancing and protecting these values. To illustrate some of the ways such normative contests play out within processes of social embedding, it is instructive to examine a few examples of such conflict within economic sectors characterised by extensive global corporate activity.

One very clear example of such conflict arises within the supply chains of global manufacturing and retail companies, in which narrow economic goals commonly come into tension with broader social, developmental and environmental concerns. Conflict of this kind confronts companies ranging from major clothing and sportswear retailers like Nike or Walmart, electronics and IT brands like Apple, global agribusiness companies like Unilever or Nestle, through to furniture retailers like Ikea. What all of these companies share in common is the sourcing and selling of their products across wideranging geographical and social spaces; this breadth is associated with a correspondingly expansive set of competing social demands. Labour and human rights activists protest about the threat of labour exploitation and so-called poverty wages; environmental and sometimes also indigenous activists demand an end to the encroachment of forests for large-scale agricultural plantations; consumers concerned about animal welfare demand products that are certified as protecting dolphins, or chickens, or migratory birds, or any of a host of other 'social' or 'ethical' causes with which they normatively identify. Such demands are not always contradictory. But more often than not, companies find themselves caught between a plurality of competing accounts of the 'social' values that they ought to be actively promoting (or at least more passively respecting).

Conflicts of these kinds have often been particularly stark when global companies have become enmeshed in large-scale processes of economic and industrial development, as is commonly the case. Such processes are often accompanied by widespread social dislocation and change, in which routine processes of social contestation are often intensified. Such conflicts have been particularly heated in relation to natural resource-intensive sectors such as mining, agribusiness and forestry (Human Rights Council 2008). In such cases, normative conflicts between concerns for environmental protection, the rights of indigenous people, protection of land tenure for subsistence farmers, and corporate-led economic development, have been intense and sometimes violent. Even a brief glance at the mining sector in PNG (Harper and Israel 1999; Filer and Imbun 2004), or the forestry and palm oil sectors in Indonesia (Colchester, Jiwan et al. 2006), for instance, reveals the intense conflicts between competing social values and interests that confront global companies operating in these sectors.

Not only do conflicts arise in relation to what kinds of social outcomes are valued, but also concerning whose concerns should be prioritised. For example, conflicts between societal groups in different geographical locations have played an important role in shaping the politics of social embedding for many global companies. In the garment sector, US retailers such as Walmart are subject to ongoing social pressure for them to support the needs of low-income American consumers by maintaining their widely touted 'always-low-prices' in American retail stores (Ortega 1999). The company has also been assailed with sustained campaigns to improve wages, working conditions and social protections for American Walmart employees. At the same time, 'antisweatshop' activists and have pressured Walmart to invest increasing resources in strengthening working conditions and social protections for workers making Walmart products in off-shore factories. 
Once again, while such demands are not always contradictory, there are some very clear examples where they do directly conflict. For example, consumer demands for low prices and up-to-date seasonal inventory in retail stores have been shown by a large body of empirical research to directly undermine demands for living wages and no forced overtime among factory workers (Ascoly 2003). Such conflicts highlight the fact that simply asking whether Walmart's global operations are 'socially embedded' would be missing the most important question of all: that is, in terms of whose social values, interests and concerns does such embedding occur?

Such examples also highlight a further important dimension of normative conflict, concerning attribution of responsibilities for promoting valued social concerns. Frequently, companies acknowledge the inherent value of objectives such as environmental protection, regulation of labour conditions in factories, and so on, and yet argue that it is not the proper role of companies to take on the responsibility of regulating social standards of these kinds. Rather, so the argument goes, one of the reasons we now so extensively resource specialised political institutions in the form of national governments is precisely so they can take on such responsibilities for embedding the economy in social values, in an effective and democratic manner. To demand that companies should be 'socially embedded' in any way that goes beyond compliance with the law would be to misunderstand this distinction between social values in general, and role-specific social responsibilities in particular. Milton Friedman's classic statement about the social responsibility of business being to increase their profits illustrates this view starkly (Friedman 1070).

In contrast, the view of many advocates of 'corporate social responsibility' for issues of these kinds has been that serious and persistent 'governance gaps' have emerged within national regulatory arrangements, thereby requiring companies (alongside non-state actors of other kinds) to take on direct responsibilities for supporting such social values, which under other circumstances might be left to governments to care for (Ruggie 2003). The emergence of a wide array of 'private' governance schemes (discussed in more detail elsewhere in this volume) are often interpreted as evidence that such responsibilities are being increasingly accepted (Haufler 2003; Vogel 2005; Macdonald 2007). Nevertheless, the appropriate attribution of responsibility to corporations for supporting social standards of valued kinds remains an important aspect of normative contestation in its own right.

\section{Competing channels of social influence over global companies}

To understand how such processes of contestation have played out in practice, we need to bring into the picture some analysis of the multiple channels through which battles to influence corporate priorities and behaviour unfold. Dominant traditions of thinking about social embedding have often conceptualised these channels of social influence through a very 'macro'-level lens (as highlighted earlier). An important point this chapter seeks to emphasise is that this needs to be supplemented with a more fine-grained 'micro' analysis of how such social forces are instantiated in particular cases. This requires that we bring competing social actors more squarely into the story, highlighting the ways in which their deliberate strategies of mobilization and claim-making interact with broader macro-sociological and historical processes in shaping the balance of social forces that come to bear on corporate behaviour. Accordingly, the following analysis teases apart some of the multiple sources of social pressure-operating through various social actors and institutions and at multiple geographical levels-through which competing sources of leverage are exerted over the behaviour of global companies, shaping the patterns of social embeddedness that emerge. 
We begin by examining some of the more diffuse, macro-sociological processes through which values, identities and expectations prevailing at a 'whole-of-society' level filter through to influence the decisions and behaviour of individual global companies.

Perhaps most obviously, the decisions of the corporate executives and managers situated at the heart of corporate command centres are influenced by diffuse processes of normative socialization, through which the perceptions, identities and values of these individuals are constituted. Such socialization processes play a similarly important role in conditioning the decisions of individual employees, investors, consumers, business partners, and others who in turn influence corporate behaviour (as discussed further below). Even without such individual actors making concerted efforts to steer company behaviour towards 'socially responsible' practices, broad shifts in social expectations can still play an important role in shaping corporate responsiveness to new issues. We can observe such diffuse processes of socialization at work by examining how corporate social responsibility agendas have evolved over time, often closely tracking broader shifts in social attitudes towards social issues of different kinds, whether these be concerns for 'sweatshop' labour, climate change, corporate tax evasion, or other issues that have waxed and waned on public and corporate agendas over recent decades (Blowfield 1999; Blowfield and Frynas 2005).

Evidence of this kind is sometimes interpreted as suggesting that companies adopting unilateral programs of corporate responsibility, signing up to voluntary certification schemes such as Rainforest Alliance or Fairtrade, or joining Multi-Stakeholder schemes such as the Common Code for the Coffee Community or Roundtable for Sustainable Palm Oil, are doing this because they have now 'got religion' in some authentic way. In other words, some suggest that rising social concern for issues such as environmental protection and global poverty has re-shaped values and identities among individual corporate managers and grassroots staff, leading the constitutive values, purposes and perceived 'interests' of companies in turn to be re-wired, to place greater weight on social alongside economic objectives.

Most observers, however, continue to question the extent to which such fundamental re-wiring of the constitutive values and objectives of major corporations has occurred. Instead, many interpret observable shifts in corporate engagement with the social responsibility agenda as a reflection of companies' more instrumental concern for social legitimation (Kell and Ruggie 1999; Campbell 2000). Social legitimacy is important in part because it enables companies to access various social 'resources' that they need to survive and prosper: legitimacy can enable them to evade intensified government regulation, draw on a willing and able workforce, attract consumers to buy the company's products, and so on. Even when prospective investors, consumers or employees of a global company do not deliberately set out to strategically influence companies through their conferral or withdrawal of 'legitimacy', the decentralised choices they make as individual workers, investors or consumers can often reflect these concerns, translating into potentially powerful forms of social influence.

One much cited story tells of the CEO of Nike at the time of intense, world-wide campaigns directed against Nike's 'sweatshop' labour practices finally yielding to activist pressure and adopting a range of corporate responsibility programs in Nike supply chains, in part because of concern that employees were becoming embarrassed at dinner parties and among family and friends to admit that they worked for Nike (Schwartz 2000). This is a classic example of how the broader social delegitimation of the company's activities filtered through to damage the company's economic interests, not only via damage to the brand from the consumer perspective, but also via the increased costs in recruiting and retaining high quality employees. Of course, as we will discuss further below, such processes of societal legitimation and de-legitimation are also often strategically 
mobilized and deployed. But the point here is that even when this is not the case, such diffuse, constitutive processes of socialization can play an important role in shaping corporate behaviour.

\section{Social embedding via market mechanisms}

Although prevailing social norms influence corporate behaviour via these broad socialization processes, employees, customers and investors also employ more overt and strategic methods of leveraging their market relationships with companies as a basis for a range of social demands.

One of the most direct and visible means through which market mechanisms have been used to promote 'social' norms of corporate conduct is the development of 'socially responsible' or 'ethical' investment schemes. In essence, such initiatives appropriate conventional market channels of corporate governance as means of broader social influence. Many pension funds and other institutional investors have developed indexes through which the ethical character of publicly listed companies can be screened and rated, thereby enabling socially-minded investors to prioritize or filter investment choices on these grounds (Sparkes 2001). Government investment agencies have also sometimes been used in this way. The Norwegian Government Pension Fund for example is overseen by an influential ethics committee which screens investments to identify those that are seen as posing an unacceptable risk of the Fund contributing to serious or systematic human rights violations, serious environmental damage, gross corruption or other serious violations of fundamental ethical norms (Chesterman 2008). In addition to proscribing investment in companies involved in 'intrinsically' unethical activities such as the manufacture of cluster weapons or antipersonnel land mines, a number of prominent companies in mainstream sectors (such as Walmart and Freeport McMoRan Copper \& Gold) have had investment withdrawn as a result of ethical concerns regarding their business operations. Such initiatives can influence corporate behaviour not only via the threat of de-investment, but also via their broader impact on shifting agendas and discourses within investor, management and business media circles towards a more detailed understanding and serious engagement with the social impacts of business activity.

Nevertheless, the increasing occurrence of 'socially responsible' investment initiatives of these kinds has in no way diminished the pressure of mainstream investors for sustained corporate performance in economic and financial terms, generating significant tensions between the economic and (broader) social demands being placed on corporate management through such channels.

The exercise of social influence via market mechanisms has also been widely documented with reference to the role of so-called 'ethical' or 'socially responsible' consumers. Increased consumer awareness and changing expectations surrounding the social and environmental conditions of production of the goods they consume have led to a proliferation of 'ethical labelling' schemes, across a range of economic sectors. To receive social certification of this kind, companies must certify their compliance with designated social or environmental standards. They can then use this label as a basis for marketing their products to 'ethically' aware consumers. Prominent examples include the Fairtrade mark, Rainforest Alliance and the Forest Stewardship Council, all of which have been widely embraced by mainstream manufacturers and retailers ranging from McDonalds, to Cadbury's, and even notorious social laggards such as Walmart (Macdonald and Marshall 2010). Such labels have been established in relation to a vast array of social causes, including organic food products, dolphin friendly tuna, free range eggs, migratory bird friendly coffee, and so on - this diversity clearly reflecting the range of conflicting 'ethical' social concerns and demands to which companies are now subject.

In these examples too, there remain important tensions between consumer demands for 'ethical' production methods, and for desirable 'economic' qualities such as competitive pricing, and desired product characteristics (Boulstridge and Carrigan 2000; Auger and Devinney 2007). Despite the 
increasing popularity of social certification and responsible sourcing schemes of these kinds, companies continue to receive extremely 'mixed messages' from consumers who say they want ethical products, but are often unwilling to sacrifice other price or quality characteristics in return.

\section{Overt social mobilization}

Strategic attempts to influence corporate behaviour occur not only via market mechanisms, but also through more conventional strategies of social mobilization, familiar to scholars of contentious politics and social activism more broadly (Tarrow 1994; Keck and Sikkink 1998; Tarrow 2005). In analysing strategic action of this kind, we can therefore draw usefully on a wider range of analytic tools than are typically applied to the topic of social embedding.

The most obvious examples in which strategic pressure of this kind has been brought to bear on global companies come from iconic corporate accountability campaigns such as those directed at Nestle on the issue of breast-milk substitutes (Dobbing 1988), Shell on gas flaring (Friends of the Earth Nigeria and Climate Justice Programme 2005; Justice in Nigeria Now 2010), Nike and a range of other garment and sportswear brands on the issue of 'sweatshop' labour (Ballinger 2010), Starbucks in relation to its purchases of Fairtrade certified coffee (Macdonald 2007), and so on. These tactics are typically grounded in recognition of the value to global companies of their brand reputation (largely because of implications for relationships with employees, investors, consumers and governments, as discussed above). On this foundation, activists then seek strategically to mobilize pressure via these multiple corporate relationships, through which their social legitimacy is secured or undermined.

Often, such market-based tactics are complemented by the mobilization of legal and political channels to intensify pressure for change. For example, social activists have creatively deployed private law mechanisms-usually designed for very different purposes-as means of pressuring companies to take social responsibilities seriously. For example, unfair competition and false advertising legislation has been used to try and hold companies accountable for claims made in their CSR marketing materials, such as in the Californian case Kasky v. Nike; 45 P 3d 243 (Cal, 2002)). A class action aiming to enforce codes of conduct also went before the Californian courts under California's Unfair Business Practices laws; this action claimed that Walmart failed to meet their contractual duty and made false and misleading statements to the American public. ${ }^{v}$

Direct forms of overt social mobilization don't always occur in ways that are this strategic and coordinated. Communities in which business operations are located often wield significant forms of influence over companies simply by virtue of the corporate interest in securing social order and compliance at such sites. In part this is simply an illustration of the broader need for companies to secure social legitimacy - or the 'social licence to operate', as it is sometimes called (Gunningham, Kagan et al. 2006). In some cases, however, the costs of illegitimacy in the form of overt social conflict can be stark. Significant management time can be taken up managing costly processes to deal with community complaints and problems around sites such as mines (Jenkins 2004). Local conflicts become even more costly when they escalate into events such as strikes, road blockages, or in the most extreme cases, such as around mining operations in Bougainville, in PNG, violent conflict that led to the shut-down of mining operations altogether in 1989 (Filer 1990).

\section{Political channels of social embedding}

For Polanyi, Ruggie and others, modern governments have always been recognised as central agents of social embedding. There is a vast array of political and sociological literature that tries to make sense of the mechanisms through which this government role can be discharged. Section 3 of this handbook addresses the role of the state in influencing global companies in greater depth. Here we 
simply sketch some of the most important political channels of social embedding-many of which interact importantly with the other social mechanisms surveyed above.

Governments use the full array of tools at their disposal to promote the embedding of corporate behaviour within valued social norms. Most obviously, traditional 'coercive' mechanisms continue to play an important role. These include constitutive vehicles like companies law, which sometimes specify company director duties in relation to social and environmental responsibility alongside core financial responsibilities. ${ }^{\mathrm{vi}}$ Many governments also make extensive use of direct forms of statutory or administrative regulation of social and environmental standards, and there are increasing moves towards requiring publicly listed companies to report on elements of their social and environmental performance. ${ }^{\text {vii }}$

More indirectly, governments often play a role in providing oversight or 'meta-regulation' of private standard-setting processes (Parker 2004), or participating directly in multi-stakeholder corporate responsibility schemes such as the Ethical Trading Initiative or Extractive Industry Transparency Initiative. They can also importantly shape corporate incentives by supporting ethical public procurement policies, or providing direct programmatic support for capacity building among businesses operating in sectors with complex social and environmental impacts. ${ }^{\text {vii }}$

Although national governments play a central role in shaping policies of these kinds, government influence over corporate 'rules of the game' can be exercised at all levels. For example, municipal governments in the United States and various European countries have played important roles in driving 'ethical' procurement programs, such as Fair Trade purchasing programs in many European municipalities, ${ }^{\text {ix }}$ and 'Sweatfree Purchasing' schemes adopted by many US counties and cities. ${ }^{x}$ And in countries that have adopted significant decentralization programs, provincial governments often play important legislative and policy making roles in relation to intensely contested issues such as land tenure and forestry regulation.

Beyond national borders, inter-governmental trade, investment, labour and environmental rules exercise increasingly powerful influence over corporate behaviour. Such international rules have been widely criticized for their tendency to proliferate voluntary (or otherwise poorly enforced) standards of corporate conduct in relation to social and environmental goals, while institutionalizing protections for the core economic interests of transnational businesses through 'hard', legally binding mechanisms. The contrast between binding investor rights protections on one hand and largely voluntary standards of investor responsibility on the other has come under particularly intense criticism (Bachand and Rousseau 2003; Mann 2008).

A less visible but equally important channel through which government action influences transnational business activity is the influence of national government policy on corporate behaviour offshore. There are some isolated examples where national governments have established social and environmental performance standards as conditions for provision of export credit, insurance or private sector development finance (Keenan 2008), or implemented explicitly extra-territorial regulations relating to egregious corporate practices such as bribery (Zerk 2010). In such cases, these interventions can provide important leverage for strengthened agendas of 'corporate social responsibility'. Conversely, national policies that encourage investors to move off-shore in pursuit of profits to be repatriated to the home country, without attendant social safeguards, generate dynamics of embedding that encourage and reward the de-prioritization of social norms of these kinds.

Interactions between competing social forces 
The above has sketched in highly schematic terms some of the most important sources of both normative contestation and social conflict that interact to shape the ways in which any given corporation will find itself socially embedded. There is a very large body of evidence indicating that the intensity of pressure to subordinate core corporate objectives to wider social goals varies significantly across different contexts, depending on variables such as the sector in which corporate activity occurs, geographical locations of production, investment and consumption, companyspecific variables, and so on. Competing social pressures can also interact in highly path-dependent and contingent ways which can be very difficult to predict. To understand variation of this kind, we need to be attentive not only to shifting ideas and social power relations at the 'whole-of-society' level, but also to the dynamics through which particular social groups are able to strategically mobilize social norms and social pressure to bring about change.

\section{Conclusion: Contested social embeddedness in a plural global order}

What then are the implications of all of this for how we make sense of the changing role of the corporation within a globalizing social, economic and political order?

This chapter's account of contemporary corporate social embedding as highly pluralist and contested has important implications for how we understand the role of the contemporary corporation in global politics. First, it highlights the positioning of companies within an increasingly multi-level global political arena. As companies themselves increasingly carve up and spread out their operations over geographical, political and social space, so too the dynamics of social and political contestation play out across multiple levels. Increasingly, companies are expected to participate in new systems of private and multi-stakeholder 'governance beyond government' (analysed in greater depth elsewhere in this volume); the terms of such arrangements are importantly shaped by the contested dynamics documented in this chapter.

More broadly, this picture of plural and contested social embedding resonates with widespread accounts of an increasingly plural global political order, in which large question marks hang over the evolution of global contests of value and power. This uncertainty sits uneasily with the tendency among many analysts to cast contemporary developments through the lens of a broader, secular trend towards more or less social embedding of some normatively specified kind. The evidence surveyed in this chapter does not support such a narrative with any clarity or confidence. In contrast, the social contest to set the terms within which corporations must operate is still very much in play, and the goal posts and terms of engagement continue to shift as distributions of norms and power in the global political economy fluctuate and evolve.

At stake in these deeply political contests are fundamental normative questions about what expectations society can legitimately place on business. Within the plural and dynamic environment of contemporary global politics, there are no clear answers to such questions, and the battles to determine whose answers will prevail remain intense. For companies such as Unilever, or the many others referred to in the examples presented above, there is no escaping the inherently political dynamics of social embedding. The clamour of contradictory local and global voices, demanding corporate responsiveness to a proliferation of social and environmental concerns, reflects clearly the multi-level, pluralist character of contemporary global politics. It is this messy, contested social order in which the contemporary socially embedded corporation is inescapably enmeshed.

\section{References}


Abdelal, R. E. and J. G. Ruggie (2009). The principles of embedded liberalism: social legitimacy and global capitalism. New Perspectives on Regulation. D. Moss and J. Cisternino. Cambridge, The Tobin Project.

Ascoly, N. (2003). Pricing in the Global Garment Industry. http://www.cleanclothes.org/ftp/03-05pricingreport.pdf, IRENE and Clean Clothes Campaign.

Auger, P. and T. M. Devinney (2007). "Do What Consumers Say Matter? The Misalignment of Preferences with Unconstrained Ethical Intentions " Journal of Business Ethics 76: 361-383.

Bachand, R. and S. Rousseau (2003). International Investment and Human Rights: Political and Legal Issues. Ottawa, Rights \& Democracy.

Ballinger, J. (2010). The threat posed by 'corporate social responsibility' to trade union rights. Fair Trade, Corporate Accountability and Beyond: Experiments in Globalising Justice. K. Macdonald and S. Marshall, Ashgate.

Beckert, J. (2009). "The Social Order of Markets." Theory and Society 38(3): 245-269.

Block, F. (2003). "Karl Polanyi and the writing of The Great Transformation." Theory and Society 32: 275-306.

Blowfield, M. (1999). "Ethical trade: a review of developments and issues." Third World Quarterly 20(4).

Blowfield, M. and G. Frynas (2005). "Setting new agendas: critical perspectives on Corporate Social Responsibility in the developing world." International Affairs 81(3).

Boulstridge, E. and M. Carrigan (2000). "Do Consumers Really Care about Corporate Responsibility? Highlighting the Attitude-Behaviour Gap." Journal of Communication Management 4(4): 355-368.

Campbell, D. (2000). "Legitimacy Theory or Managerial Reality Construction? Corporate Social Disclosure in Marks and Spencer PLC corporate reports 1969-97." Accounting Forum 24(1): 80-100.

Chesterman, S. (2008). "The Turn to Ethics: Disinvestment from Multinational Corporations for Human Rights Violations - The case of Norway's Sovereign Wealth Fund." New York University Public Law and Legal Theory Working Papers 84.

Colchester, M., N. Jiwan, et al. (2006). Promised Land Palm Oil and Land acquisition in Indonesia implications for local communities and indigenous peoples, Forest Peoples Program, Perkumpulan Sawit Watch, HuMA and the Worls Agroforestry Center.

Dobbing, J. (1988). Infant Feeding: Anatomy of a Controversy, Springer-Verlag.

Filer, C. (1990). "The Bougainville Rebellion, the Mining Industry and The Process of Social Disintegration in Papua New Guinea." Canberra Anthropology 13(1).

Filer, C. and B. Imbun (2004). "A short history of mineral development policies in Papua New Guinea." Working Paper No. 55 Resource Management in Asia Pacific, Research School of Pacific and Asian Studies, Australian National University.

Friedman, M. (1070). "The Social Responsibility of Business is to Increase its Profits." The New York Times Magazine September 13.

Friends of the Earth Nigeria and Climate Justice Programme (2005). Gas Flaring in Nigeria: A Human Rights, Environmental and Economic Monstrosity. Amsterdam, Friends of the Earth Nigeria / Climate Justice Programme.

Gemici, K. (2007). "Karl Polanyi and the antinomies of embeddedness." Socio-economic Review 6: 533.

Granovetter, M. (1985). "Economic Action and Social Structure: The Problem of Embeddedness." The American Journal of Sociology 91(3).

Gunningham, N., R. Kagan, et al. (2006). "Social Licence and Environmental Protection: Why Businesses Go Beyond Compliance." Law \& Social Inquiry 29(2): 307-341.

Hall, P. A. and D. Soskice, Eds. (2001). Varieties of Capitalism. The Institutional Foundations of Comparative Advantage. Oxford, Oxford University Press. 
Harper, A. and M. Israel (1999). "The killing of the Fly: State-corporate victimisation in Papua New Guinea." Working Paper No.22 Resource Management in Asia Pacific Series.

Haufler, V. (2003). New forms of governance: certification regimes as social regulations of the global market. Social and Political Dimensions of Forest Certification. E. Meidinger, C. Elliott and G. Oesten.

Human Rights Council (2008). Promotion and Protection of all Human Rights, Civil, Political, Economic, Social and Cultural Rights, including the Right to Development; Protect, Respect and Remedy: A Framework for Business and Human Rights; Addendum 2: Survey of Scope and Patterns of Alleged Corporate-Related Human Rights Abuse. Report of the Special Representative of the Secretary General on the issue of human rights and transnational corporations and other business enterprises, John Ruggie, Human Rights Council.

Jacoby, S. (2004). The Embedded Corporation. Princeton, Princeton University Press.

Jenkins, H. (2004). "Corporate social responsibility and the mining industry: conflicts and constructs." Corporate Social Responsibility and Environmental Management 11(1): 23-24.

Jessop, B. (2001). The Social Embeddedness of the Economy and its Implications for Economic Governance, http://www2.cddc.vt.edu/digitalfordism/fordism materials/jessop2.htm.

Justice in Nigeria Now (2010). Gas Flaring in Nigeria: an Overview, April 2010. San Francisco, Justice in Nigeria Now.

Keck, M. E. and K. Sikkink (1998). Activists beyond borders: advocacy networks in international politics. Ithaca, N.Y., Cornell University Press.

Keenan, K. (2008). Export Credit Agencies and the International Law of Human Rights. Ottawa, Halifax Initiative.

Kell, G. and J. G. Ruggie (1999). "Global Markets and Social Legitimacy: The case of the Global Compact." Transnational Corporations 8(3).

Krippner, G. and A. Alvarez (2007). "Embeddedness and the Intellectual Projects of Economic Sociology." Annual Review of Sociology 33.

Krippner, G., M. Granovetter, et al. (2004). "Polanyi Symposium: a conversation on embeddedness." Socio-Economic Review $\mathbf{2}$.

Macdonald, K. (2007). "Globalising justice within coffee supply chains? Fair Trade, Starbucks and the transformation of supply chain governance." Third World Quarterly: Special Issue on 'Beyond CSR? Business, Poverty and Social Justice' 25(7).

Macdonald, K. (2007). Public accountability within transnational supply chains: A global agenda for empowering southern workers? Forging Global Accountabilities: Participation, Pluralism and Public Ethics. A. Ebrahim and E. Weisband. Cambridge, Cambridge University Press.

Macdonald, K. and S. Marshall, Eds. (2010). Fair Trade, Corporate Accountability and Beyond: Experiments in Globalizing Justice. London Ashgate.

Mann, H. (2008). International Investment Agreements, Business and Human Rights: Key Issues and Opportunities, International Institute for Sustainable Development.

Marshall, S., R. Mitchell, et al., Eds. (2008). Varieties of Capitalism, Corporate Governance and Employees. Melbourne, Melbourne University Press.

Mikler, J. (2009). Greening the Car Industry: . Cheltenham, Edward Elgar.

Ortega, B. (1999). In Sam We Trust: The Untold Story of Sam Walton and Walmart, the World's Most Powerful Retailer, Kogan Page.

Parker, C. (2004). "Meta-Regulating Corporate Governance: Legal Accountability for Corporate Social Responsibility?".

Polanyi, K. (1944). The Great Transformation: the political and economic origins of our time. Boston, Beacon Press.

Polanyi, K. (1957). The great transformation. Boston, Beacon Press.

Ruggie, J., Ed. (2008). Embedding Global Markets: An enduring challenge, Ashgate.

Ruggie, J. (2008). "Protect, Respect and Remedy: A Framework for Business and Human Rights." Innovations: Technology, Governance, Globalization 3(2): 189-212. 
Ruggie, J. G. (1982). "International Regimes, Transactions, and Change: Embedded Liberalism in Postwar Economic Order." International Organization 36(2).

Ruggie, J. G. (2003). Taking Embedded Liberalism Global: The Corporate Connection. Taming Globalization: Frontiers of Governance. D. Held and M. Koenig-Archibugi. Cambridge, Polity Press.

Schwartz, P. (2000). "When good companies do bad things." Strategy \& Leadership 28(3): 4-11.

Sen, A. (2009). "Capitalism Beyond the Crisis." The New York Review of Books 56 (5).

Sparkes, R. (2001). "Ethical Investment: whose ethics, which investment." Business Ethics: A European Review 10(3): 194-205.

Tarrow, S. (1994). Power in movement: social movements, collective action and politics. Cambridge, Cambridge University Press.

Tarrow, S. (2005). The New Transnational Activism. New York, Cambridge University Press.

Utting, P. (2005). Rethinking Business Regulation: From Self-Regulation to Social Control. UNRISD Technology Business and Society Programme Paper Number 15. Geneva, UNRISD.

Vogel, D. (2005). The market for virtue : the potential and limits of corporate social responsibility. Washington, D.C., Brookings Institution Press.

Zerk, J. (2010). Extraterritorial Jurisdiction: Lessons for the Business and Human Rights Sphere from Six Regulatory Areas. Working Paper No. 59, Harvard Corporate Social Responsibility Initiative.

\footnotetext{
i www.unilever.com/aboutus; accessed August 2012

ii http://www.unilever.com/images/Global\%20Challenges\%20Local\%20Actions tcm13-5100.pdf, accessed August 2012

iii See for example a range of authors collected in a 2004 special issue of Socio-Economic Review addressing the topic of embeddedness (Krippner, Granovetter et al. 2004).

${ }^{\text {iv }}$ This view resonates with that of Granovetter (cited in (Krippner, Granovetter et al. 2004): “For me [the concept of embedding] is just an announcement or a conceptual umbrella under which one should look into and think about what are the connections between economic activity and the social, the political, the institutional, the historical, the cultural elements that economic activity is mixed up with. So it is a sensitizing umbrella concept and that is how I have come to use it, because I think anything else will just get us into endless debates."

"See www.laborrights.org

${ }^{\mathrm{vi}}$ For a discussion of changes to Director Duties in the UK, see for example: http://corporateresponsibility.org/wp-content/uploads/2009/09/Companies Bill Supporter Verdict Long Nov06.pdf (accessed August 2012)

vii See for example: http://ec.europa.eu/enterprise/policies/sustainable-business/corporate-socialresponsibility/reporting-disclosure/index en.htm and http://www.sec.gov/spotlight/doddfrank/speccorpdisclosure.shtml, both accessed August 2012

viii See for example: http://www.pm.gc.ca/eng/media.asp?category=1\&featureld=6\&pageld=26\&id=4435

${ }^{\text {ix }}$ See

http://www.europarl.europa.eu/RegData/bibliotheque/briefing/2012/120334/LDM BRI(2012)120334 REV1 EN.pdf

${ }^{\mathrm{x}}$ See http://buysweatfree.org/about
} 


\section{University Library}

\section{- M M I E R R V A gateway to Melbourne's research publications}

Minerva Access is the Institutional Repository of The University of Melbourne

Author/s:

Macdonald, K

Title:

The Socially Embedded Corporation

Date:

2013-03-26

Citation:

Macdonald, K. (2013). The Socially Embedded Corporation. Mikler, J (Ed.). The Handbook of Global Companies, (1), pp.371-387. Wiley.

Persistent Link:

http://hdl.handle.net/11343/91839 